\title{
医·薬連携大学院による名城大学の臨床薬剤師教育
}

\author{
松葉和久
}

\section{Clinical Pharmacy Practice Education in Master's Course of Meijo University in Affiliation with Medical School}

\author{
Kazuhisa MATSUBA \\ Meijo University, Faculty of Pharmacy, 150 Yagotoyama, Tenpaku-ku, Nagoya 468-8503, Japan
}

(Received April 13, 2009)

\begin{abstract}
In 2003, Meijo University has developed a new program to train students in master's degree in the field of clinical practice. This new curriculum has three big pillars of educational goal: Problem-Based Learning (PBL), communication skill and clinical pharmacy practice training. Before exposing students to clinical training, they must learn first how to solve various patients' problems through PBL and enhance their communication skill. To provide a clinical environment, education and training, the Faculty of Pharmacy cooperated with the School of Medicine of Fujita Health University. Master's students together with other members of the healthcare team observe patient's disease state and most especially monitor pharmacotherapy. At first, students will be trained for a month at the pharmacy division and experience one week-nursing job. Next, they will be trained at the clinical divisions such as General Internal Medicine, Cardiology, Endocrinology, Gastroenterology, Respiratory Medicine, Hematology, Chemotherapy, Gastroenterological Surgery, Psychiatry, and Emergency Unit. Students rotate three-month training on four clinical divisions during one year. The head physicians of the medical department hold concurrent post as professors and share responsibility with the pharmacy faculty in training the students. To have its venue where students, faculty and physicians conduct their discussion on clinical cases, a pharmacy satellite seminar class room was set up at Fujita Health University hospital. Through this, pharmacy students and faculty had more opportunities to exchange knowledge on medicine and pharmacy. Master's students are expected to acquire professionalism, ethical knowledge and pharmaceutical care skills through the clinical pharmacy practice program.
\end{abstract}

Key words_— clinical pharmacy practice; pharmacy education; problem-based learning; communication skill; pharmaceutical care; satellite seminar class room

\section{1.よりスキルアップした臨床薬剤師教育}

1-1. 薬学専攻科から大学院臨床技能コースヘ 2003 年 4 月に開設された名城大学の大学院薬学 研究科臨床薬学専攻臨床技能コース（以下; 技能 コース）における教育理念は，過去 28 年間の薬学 専攻科教育を礎とした，薬物治療への本格的な参画 を目指した臨床薬剤師の養成にあり，薬剤師として 患者の病態と医師の治療方針, 薬物療法の合理性を 理解し, 薬物療法の有効性と安全性に対して患者へ の責任を果たすことにある.

名城大学は 1975 年に医療現場における薬剤師職

名城大学薬学部（４468-8503 名古屋市天白区八事山 150)

e-mail: matsuba@ccmfs.meijo-u.ac.jp

本総説は, 平成 20 年度退職にあたり在職中の業績を中

心に記述されたものである。
能の発展とレベルの向上を図るために，実践的教育 に特化した 1 年コースの薬学専攻科を開設した。こ の薬学専攻科は患者の薬物療法と病状の推移に係わ るベッドサイド教育にあった。当初は，薬剂師の病 棟活動は医療関係者に理解されず，苦難の時代であ つたが，「病棟活動を中心として実務能力のある臨 床薬剤師の養成」を目標とした，28 年間の臨床薬 学教育は先駆者としてその分野を開拓したのであつ た。 日本の薬剤師養成のための医療現場における実 務教育への取り組みは医師・看護師など他の医療職 種を養成と比べて遅れていたが，薬学教育も 6 年制 の新体制へ移行して，実務実習を必修とした教育が 始まったことは大きな前進である.

1-2.「薬学教育の改善について（最終のまとめ）」 新大学院の「技能コース」設置にあたつては, 1996 年 3 月に文部省高等教育局長へ薬学教育の改 
善に関する調査研究協力者会議（主査：南原利夫） が報告した「薬学教育の改善について（最終のまと め)」を参考とした。この報告書は大学院薬学研究 科修士（又は博士前期）課程に医療薬剤師の養成の ためのコースの設置を提言したものであった。その モデルカリキュラムとして, 医療倫理, 臨床心理, コミュニケーション論, 医薬品情報学に加えて, 薬 局管理学, 薬剤疫学, 看護学概論, 臨床検査学, 薬 剂学 (臨床薬剂学, 薬物動態学, 薬物処方学, 臨床 医学概論 I, 同 II (薬物療法学), 医療統計学を提 案している. また, 今後の病院薬剤師教育は, 臨床 実務実習を通して医療人としての自覚の醸成ととも に, 臨床現場における問題解決や問題提起の能力の 啓発が必要であるとして, 座学では得られない技 能・態度を習得する実務実習の必要性を強調してい る（以下，本文では薬剤師免許を持っていない医療 現場教育を「実習」とし，薬剂師免許を持って行う 場合を「研修」と表現した)。「自覚の醸成」とは倫 理観の修得であり，職業倫理は専門職 profession の教育では必要不可欠な部分である。技能コースは 問題提起能力, 問題解決能力の養成を強く意識し た. 同報告書は「問題提起能力，問題解決能力のよ うな資質は研究体験からの夕修得できる」としてい るが，技能コースではこの問題解決能力養成手段と $し て$, 問題解決型学習 (PBL; problem-based learning）を導入した.

臨床現場を背景とする教育では, 現場スタッフで ある医学部教員, 医師, 病院薬剤師, 及び看護師な ど多くの医療従事者の現場指導者（メンター; mentor）としての協力が不可欠である.この教育 環境の実現のために, 2003 年に名城大学は藤田保 健衛生大学医学部と医・薬連携大学院協定を締結 し, 全国で初めての臨床薬剤師を養成する「医・薬 連携大学院」を開設した。医・薬連携大学院では, 薬学研究科の大学院生は藤田保健衛生大学病院にお ける医療チームの一員として, 日常の診療活動に参 加して研修を受けることが可能である.この医・薬 連携による臨床薬剤師養成教育では, 医学部と薬学 部の双方の教員から指導が行われる，従来の薬学生 の実習／研修領域だった病院薬剤部の枠を超えて, 病院全体を研修の場とした学際的な薬剤師の臨床技 能教育を構築したのであった（Fig. 1).

この学際的な大学間連携教育は両大学の全学的な

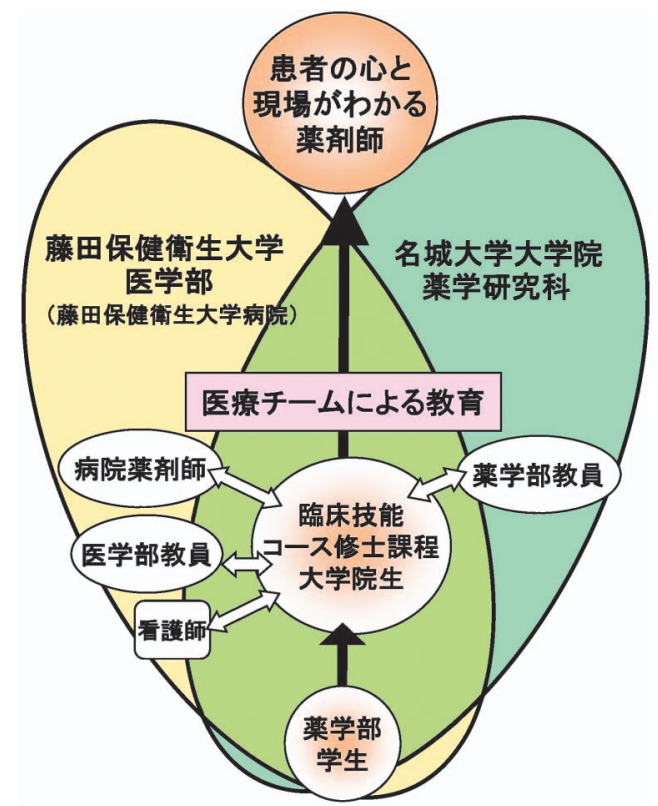

Fig. 1. The Environmental Structure of Clinical Pharmacy Practice Training for Master's Students in Meijo University

支援によって実現した。医学部を有さない全国の私 立薬科大学・薬学部にとって, この医・薬連携は実 務教育の 1 つの方策であり, 薬科学の発展のために 参考となることを期待したい.

1-3. 2 本の柱で支える臨床薬剂師研修臨床 医学系講義の病態生理学, 臨床検査学, 症候論, 薬 物治療学などは相互に関連性が強く, これらを別々 に講義することは効率が悪いため, 一括してオムニ バス形式の講義を採用した. 臨床薬物治療学 (4 単 位) と臨床薬物動態学 (4 単位) の 2 つの専修科目 に集約して, PBL による統合学習とした。この学 習法は知識の獲得とともに, 問題解決を習得する学 習法でもある。臨床薬剤師として患者の情報を収

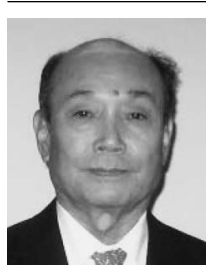

松葉和久
昭和 37 年 岐阜薬科大学製造薬学科卒 業, 名古屋市立大学病院薬剂部, 昭和 43 年同医学部生化学教室研究員 (平成 3 年まで), 昭和 51 年医学博士 (名古 屋市立大学), 平成 3 年名古屋市立大学 病院薬剂部長・同大学薬学部客員教 授, 平成 6 年愛知県病院薬剂師会会 長 - 日本病院薬剂師会理事, 平成 11 年 名城大学薬学部教授・薬学専攻科長, 平成 15 年薬学専攻科を改組した大学院 臨床薬学専攻臨床技能コース長, 「医・ 薬連携大学院による臨床薬剂師教育」 が平成 16 年度文部科学省「特色ある大 学教育支援プログラム」（特色 GP16） に採択. 平成 21 年退職. 
集，統合化する技能習得にも適している.

その他の特徵的な科目として, 海外臨床研修（2 単位, 選択）がある. 名城大学薬学部が交流協定を 結ぶ米国アラバマ州バーミングハム市の Samford 大学薬学部の学生とともに, 現地の医療施設での臨 床実習 (APPE; advanced pharmacy practice experiences）に参加し，症例検討に参加することは, 彼らに大きなモチベーションを与える。 また，医療 英語コミュニケーション特論 ( 2 単位), 薬剤疫学・ 医療統計学特論（2 単位）も必修科目とした。

Figure 2 に技能コースにおける教育の概念図を示 した. 本教育の特徵は臨床薬物治療学々臨床薬物動 態学にPBL を導入したことと, 臨床コミュニケー ション学特論（2 単位）に重きを置いた点にある. コミュニケーション・スキルは患者から病(やまい) に関する情報の収集に必要不可欠なスキルである. この講義では演習を主体としてスキルを重視し，こ の学習評価に客観的臨床能力試験 (OSCE; objective structured clinical examination）を薬学教育で初 めて導入した. ${ }^{1)}$ 各診療科での研修は「臨床薬物治 療学臨床研修・演習（16 単位)」及び「臨床薬物動 態学臨床研修・演習 (16 単位)」とした。この臨床 研修・演習は 3 週間の「薬剂部研修」と 1 週間の 「看護体験」を含む．看護については多くの学生は 医師の補助業務としてのイメージを持つが，看護師 とともに行動することで，看護師が「患者の生活を 支える」という固有の職能と病棟の管理という職務 を有することを理解する。この看護体験は病棟での 大学院生の臨床研修を円滑に進める点で意義のある

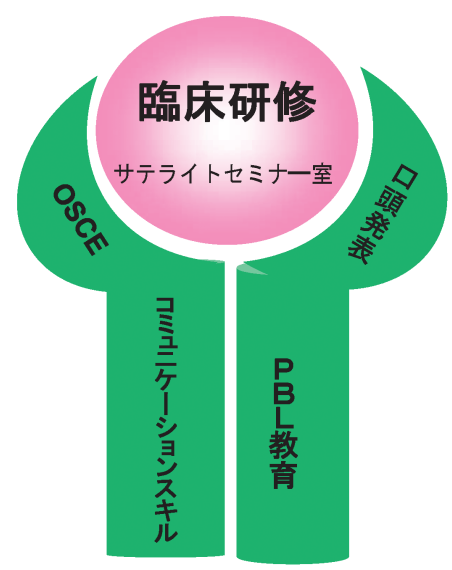

Fig. 2. Clinical Pharmacy Practice Training Supported with PBL and Communication Skill
体験となる.

技能コースの臨床研修は米国の APPE を参考と したが，本コースの大学院生は既に薬剂師免許を有 しているため，結果的に米国のレジデント制度に近 い臨床研修となった。大学院生は指導医のもと各診 療科を 3 力月単位でローテートし，病棟及び外来で 患者と接触する. 1 年生の 10 月から始まり 1 年 3 カ月の長期にわたり，大学院生は直接医師と行動を ともにして患者のケアに参加し，実症例に接して問 題解決能力を養い，薬剤師の臨床現場での役割と責 任を考える．最終的に大学院生は，彼らが研修中に 経験した 1 症例を修士論文にまとめる。

\section{2. 臨床コミュニケーション学}

2-1. 臨床コミュニケーション・スキル＼cjkstart臨床 技能コースでは薬学的知識の習得に加えて, コミュ ニケーション教育の「技能」及び「態度」教育に本 教育の重要性を求めた。本講座では患者面接で薬物 療法に関与するあらゆる情報を引き出すスキルを得 ることが目的である，大学院生は「医療面接」を軸 に，薬剤師が現場で直面する種々な技能を模擬体験 的に学ぶ．今日の医療は患者との対話が原点であ る. 医療コミュニケーションは薬学教育の分野では 新しい教育であり, 藤田保健衛生大学医学部医学教 育企画室の協力を得て，患者・家族との信頼関係を 構築し, 診断・治療に必要な情報を得るための薬剤 師の医療面接を中心に，コミュニケーション教育の 開発を進めながらの臨床薬剂師教育であった。

医師と同様に，患者の解釈モデル，受療行動の理 解に努め, 患者と医療者の間の信頼関係を構築する 能力の習得がこの教育の目標となる．患者との信頼 関係は共感を得ることによって成立する，特に患者 との対話を重視した医療 narrative-based medicine ${ }^{1,2)}$ が，今日強調されてきている。 また，今日の医療の 在り方がインフォームド・コンセントに代表される ように，医療における情報弱者としての患者の自律 autonomy の尊重が原点である．その意味で医療に 係わるコミュニケーションの根源は臨床倫理学に求 められよう。

2-2. OSCE 医療におけるコミュニケーショ ンの基本的な形を模擬患者（SP; standardized patient）との医療面接によって学ぶことは，臨床 薬剤師教育には不可欠である。コミュニケーション 講義の進め方は薬剤師が患者に係わる場面，あるい 
は医師との係わりをシナリオに設定し，ロールプレ イを中心に実践的に学習する. 最後に彼らのコミュ ニケーション・スキルは OSCE によって評価され る.

名城大学は 2003 年 7 月に, 9 名の技能コースの 大学院生に対して 5 ステーションの OSCE を実施 した。これは日本で初めて薬学生に対して実施され た本格的な OSCE であった。 ${ }^{3)}$ OSCE では受験生は 試験場で提示された症例シナリオを読んで SP と対 応する.この試験の客観的評価を確保するために, 評価者へは薬学部の教員に加えて，今後彼らが臨床 研修を始める藤田保健衛生大学医学部の教員・薬阂 部長も外部評価者として参加のお願いをした。 OSCE の評価はその場で受験者にフィードバックさ れる，受験者である大学院生はこの試験に合格して 臨床研修に臨む。また，OSCE の評価の客観性を確 保するために本試験を一般公開とした。主なロール プレイ及び OSCE のシナリオには下記の場面が設 定された；1）電話による処方せんの疑義照会，2) 院内感染防止のための患者へ手洗い・手指消毒の方 法の説明，3）点眼適用方法の説明，4）服薬指導, 5）喘息薬吸入器の使用方法，6）ピークフローメー ターの使用方法説明.

2-3. コミュニケーション教育の開発 臨床薬 剂師に必要な技能と態度を理解し習得することがコ ミュニケーション教育であった。この分野は薬学教 育では経験が浅く, 岐阜大学医学教育開発研究セン ターの協力を得て, 1 年 1 回の「特色 GP16 支援に よるワークショップ」を 4 回開催した. ${ }^{4-7)}$ 全国か ら多くの薬学教育者がこれらワークショップに参加 し，薬学領域におけるスキル教育について議論され た. 2005 年から 2008 年における議論の課題から薬 学教育者の本教育への関心とその変遷を知ることが できる．第 1 回「模擬患者を活用したロールプレイ 教育の必要性について」では, 薬学分野でのコミュ ニケーション教育の必要性を確認するとともに，コ ミュニケーション教育の最も重要で主要な方法ので ある SP の薬学分野での活用の方法とそのために必 要な教材について議論された.

第 2 回「コミュニケーション教育の教材・患者用 シナリオの作成」では，患者用シナリオの作成の方 法を学び，それを用いてロールプレイを体験するこ とを中心にコュニケーション教育の方法論が学ばれ
た．SP が患者を演ずるシナリオは薬剤師が臨床に おいて安全に適切な薬物療法を支援するための教材 として重要である.

第 3 回「薬学分野のコミュニケーション教育にお ける効果的なフィードバックの方法」では，ファシ リテーターやSP としての立場から学生へフィード バックすべき評価の内容，方法について議論され た。特に，教員によるファシリテートをより効果的 にするための方法を学んだ.

第 4 回「OSCE で終わらないコミュニケーション 教育を目指して」が開催された，新しい 6 年制薬学 教育が始まり，コミュニケーション教育の認識が深 まってきていたが，多くの薬学者はコミュニケーシ ヨン教育の内容よりも OSCE へ関心が偏在する傾 向にある。第 4 回目の研修では，OSCE はコミュニ ケーション教育の目標ではなく, 薬学生が患者を正 しく認識することが教育目標であることを再確認す ることにあった。

コミュニケーション教育は 6 年制薬学教育でも重 視される．新コアカリキュラムもその GIOに「相 手の気持ちを配慮する」を挙げている。 また，この GIO には下記の 5 項目の SBOs が列挙されてい る；1）病気が患者に及ぼす心理的影響について説 明できる，2）患者の心理状態を把握し，配慮する (知識・態度)，3）患者の家族の心理状態を把握し, 配慮する (知識・態度)，4）患者やその家族の持つ 価值観が多様であることを認識し，柔軟に対応でき るよう努力する (態度)，5）不自由体験などの体験 学習を通して患者の気持ちについて討議する（知 識・態度)。これら SBOs を学生に理解させるため には，臨床心理学，特に Kuebler-Ross ${ }^{8)}$ に始まるサ イコオンコロジーのような医療心理学と臨床倫理学 の分野が欠かせない。コミュニケーション教育に重 要なシナリオ作成もこのような背景を配慮すること が望ましい。医療におけるコミュニケーションは接 遇のトレーニングではない。科学的に患者を理解す る不可欠な技能であり，既に医学教育や看護教育で は普遍的な教育法である，薬学教育においてもこの 分野の重要性の認識が痛感される。

\section{PBL}

3-1. PBL 教育の特徵 PBL は大学院生が臨 床研修に入る前の事前教育として，最も重要な教育 手段として導入された。学生に自主性を持たせた小 
グループで行う統合的な学習である，大学院生は 1 年前期に 1 テーマ 1 週間のスケジュールで PBL に 取り組む。最初のコアタイム（90 分）で与えられ たシナリオを分析する.グループは提示されたシナ リオ（教材）の問題点を分析し，何が起きているか 複数の仮説を挙げ，解決する方策を提案する．未知 な事柄や不明な用語などは学習課題 learning issues として取り上げて参考書・文献を検索して自己学習 し，問題解決に役立てる。グループは自主的に数回 集まって学習内容の意見交換，統一を図る，最終の コアタイム（90 分）で学習課題の内容と仮説・解 決策が発表され，医系・薬系教員と議論が交わされ る.一般的にはグループの学習にはテューターが同 席し，議論の方向性をアドバイスするスタイルを PBL テュートリアルと呼ぶ。名城大学の PBL で は，教員はむしろファシリテーターとして学習の促 進役を担うだけである。そのため本稿では“PBL テュートリアル”ではなく“PBL”として表現し た．PBL はひとつの教育手段である，自己学習を 身につける成人学習理論 andragogyに分類され る．伝統的な教育手段である講義では，教育者は知 識（事実）や論理を学生にまず教える。成人学習で はこのような考え方は単なる教育者の願望の反映に

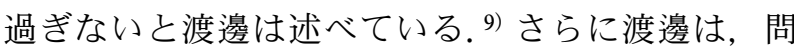
題解決型学習理論は Knowles ${ }^{10)}$ によって 1970 年代 に提唱された成人を対象とする教育であり，「主に 議論を通して個人の学習は促進される」とし，学習 とは「学習者自身がある面である程度に自らのニー ズを満たすために，新しい技能や考えを創り出すプ ロセス」であると説明している，PBL では，学習 者は自ら問題・課題を抽出し，設定して，それを考 え，考察を含めて能動的学習態度を学び，問題解決 能力を養成する。この学習法によって学習者はより 深い「知識」を獲得する。また，教師の役割はその プロセスを導くことにあるとしている．教育学的に は, ${ }^{11)}$ PBL は知識を獲得して自己判断力を高める, いわゆる知識を体系化せしめることから，認知領域 に分類される．PBL 学習のプロセスでは，学生は 断片化された不明な情報を整理・集約して，「何が 起きているか」を統合的に理解して，より深く記憶 された知識を獲得する。このプロセスを経た知識が 記憶に残る知識とされる．PBL など小グループ学 習の利点としては，また学生たちがお互いに教え合
う機会を持つことにあるとされている。「教えるこ とは習うこと」である。自分の知識を他人に伝える ためにはその知識の理解を確かなものとしなければ ならない。この省察が知識を確かなものとし，より 深い記憶とする.

埋もれた概念を探索することに不慣れな学生のた めに, 名城大学では KJ 法を取り入れている. ${ }^{12,13)}$ 隠れた真実（問題点）の抽出手段として，KJ 法の 利用は有用である，KJ 法は通常，脳内の認知領域 の思考のプロセスを紙上でビジュアルに行う。パズ ルのように短文で表現された事柄・事実を組み合わ せて 1 つの概念を構成する．いわゆる「意識を外化 する」作業である。これによって学習グループ間の 認識が共有される利点がある。初心者にとって, $\mathrm{KJ}$ 法は多くの時間を要する作業であるが，シナリ オに潜む事象を浮かび上がらせて明確にする点で有 用である。

3-2. 臨床技能教育に最適な PBL PBL は医 学教育では普遍的な教育となりつつあるが, 薬学教 育では薬剤師の臨床技能教育への理解がいまだに浅 く，本格的な活用には至っていない。筆者らは 2005 年 6 月に全国の薬学教育の教務関係者へ PBL の導入状況について調査した。 この時点で PBLの 「経験あり」と回答した大学は 15 校で，そのうち 8 校が 1 年次で導入していると報告していた。名城大 学も 1 年生へ PBL 導入を始めているが，低学年で は資料調査・文献検索能力が低く，むしろ小グルー プ学習 (SGL; small group learning) の色合いが強 い。一方，高学年で本格的な PBL を経験をした大 学としては 7 大学から報告されていた. ${ }^{14)}$

Woods ${ }^{15)}$ は，学習の向上は学生が主体的な場合 や学生同士が協力する場合と学習計画の一部を自分 で作る場合であると述べている．PBL はグループ 学習によって，患者に係わる医療情報を収集して， それらの情報から何が起きているかを割り出し, 患 者の問題点を解決する方法を学ぶ学習法である。こ の学習法は多くの時間を必要とするが, じっくりと 薬剤師の臨床技能を養う学習法である。この学習法 によって学生たちが些細な事柄も切り捨てずに考察 し，議論する習慣を習得する点も見逃せない特徵で ある．医療は不確実性の学問と言われる。些細な事 柄を見逃さずに議論する習慣が医療の安全の文化を 作り上げ，医療の質を向上させる. 
今日, PBL は医学, 看護, 獣医, その他の医療 従事者を養成する教育分野で積極的に導入が図られ ている. 名城大学の技能コースでは, 臨床薬物治療 学と臨床病態解析学特論に PBL を導入し, 医療現 場で遭遇するであろう種々の症例を多角的にグルー プ学習によって学ぶ。この学習では基礎的な知識と ともに極めて実践的な臨床知識をも学ぶ. 臨床薬剤 師を養成する教育へ PBL を取り入れることは，薬 剂師として疾病を理解して薬物療法の正当性・問題 点を明らかにする手法を学ぶことである。この反復 学習が専門職としての薬剤師の技能熟達への道を開 く．大学院生たちは将来, 臨床現場で体験する種々 の症例を PBL によってバーチャル体験し，臨床薬 剂師としての技能を学ぶ.

PBL によって養われる基本的な学習能力として 下記の 5 点が挙げられよう；1）問題解決能力，2) 自己学習能力，3）協同作業（グループワーク），4） 自己評価能力，5）科学的根拠に基づいた論理思 考。臨床薬剤師に必要な問題解決能力とは, 患者が 受ける薬物療法に責任を持つことである，臨床薬剤 師は症候論, 病態生理学, 疫学などの医学的知識か ら臨床倫理学的，社会医学的問題をも含めた幅広い 統合的な知識をこの学習では動員しなければならな い. PBL 学習を終えたときの大学院生の感想では, PBL による問題点抽出の経験に満足し，臨床現場 でなすべきことがよく理解でき，不安を払拭できた と述べている.

3-3. SOAP と FARM 通常, 診療記録は問 題志向型医療記録 problem oriented medical record によって記録される。医師も看護師もSOAPを使 つて記録することが一般的である。薬剤師も SOAP を使って経過記録欄へ記録する．PBLを薬 剂師教育へ導入する意義は，PBL が臨床現場にお ける臨床薬剂師の行動をバーチャル・シミュレーシ ヨンにあることは既に述べた．PBL は薬物療法上 の解決すべき問題点を明確にする薬剤師の思考過程 を獲得する「精神運動領域に分類される学習」であ る. 患者の自・他覚所見や訴えから薬物療法の適正 性を考えることを学習目標として，学生は与えられ た教材に基づいてグループで議論し，何が原因か, その解決策を考え, 薬剤師の行動目標を決める.

PBL は薬剤師の思考プロセスであるSOAP のロ ジックを整理する学習としても最適である。医療現
場では，薬剤師は SOAPによって得た具体的行動 プラン（P）を最終的に医療チームへ具体的に提案 することが薬剤師の責任である，患者の訴えなど医 療者が確認しない情報（S）と客観的に医療者が観 察した身体所見，臨床検査值などの情報 $(\mathrm{O})$ から， 患者の抱える問題を仮説として提起し，その解決策 を得るための学ぶべき知識を学習課題として列挙 し，それらを調査し，考察に利用する. 問題点解決 に必要とされる参考資料・文献・ガイドラインに基 づいて症例を評価し（A），薬剤師が取るべき患者 の薬物療法に対する具体的・必然的な行動プランを 提案する (P) (Fig. 3).

6 年制薬学教育のモデル・コアカリキュラムでは, SOAP に関する学習を「医薬品情報」と実務実習 の「薬剂管理指導業務」で学ぶが, 恐らく十分な学 習時間を得ることは難しい，PBL やSOAP の学習 は, ケーススタデイにおける臨床所見の的確な抽 出，正しい観察と判断力，知識を統合的に動員する 作業を学ぶ学習である。臨床実務実習・研修の前 に，現場で遭遇する可能性の高い，患者に係る情報 の処理を PBL で疑似体験させることが最も効果的 な技能獲得の学習である. じっくり議論し，論理の 構築を学ぶ PBL は大学の教室で行うからこそ多く の時間を費やすことが可能である．多忙な医療現場 でこのような教育法はあまり適切ではないといえる.

ここにSOAP に代わるもう 1 つのロジックが提 案されている，薬剤師のケアに焦点を合わせて体系

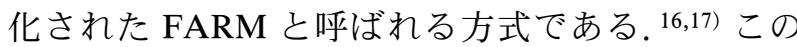
方式では薬剤師は患者の薬物療法に絞って観察し, 薬物療法が抱える問題点を抽出し $(\mathrm{F})$, その問題

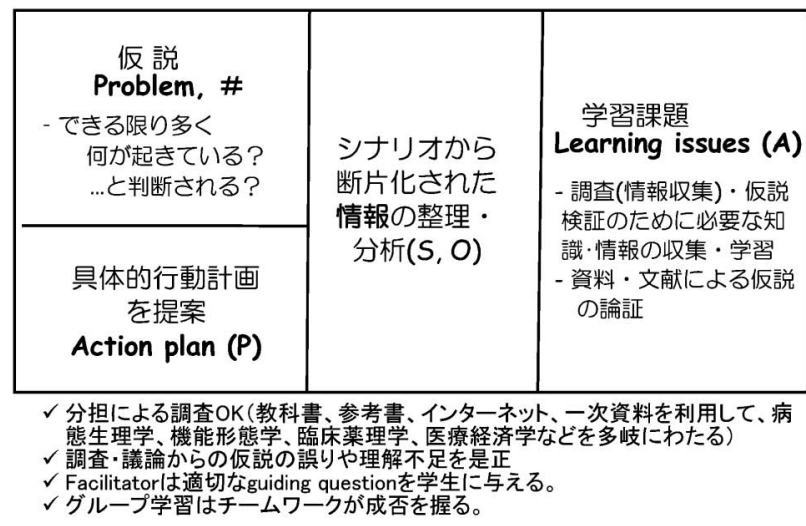

Fig. 3. Learning SOAP with PBL 
点をモニターするパラメータは何かを評価し (A), 治療計画へ提案し（R)，それらのパラメータをモ ニタリングする $(\mathrm{M})$ ）この FARM のロジックは 薬剤師の行う薬物療法監視に焦点を合わせている. このプロセスを PBL で習得することで，薬㓮師の 臨床技法を学ぶことができる.

\section{4. 臨床研修}

4-1. 臨床技能教育 名城大学が始めた 1 年 コースの薬学専攻科では 4 力月程度の臨床研修であ つたが，2003 年 4 月に改組された大学院臨床薬学 専攻「臨床技能コース」では，大学院生は 1 年以上 の期間を臨床現場で学び，より臨床技能の習得に特 化した修士課程となつた。臨床研修を担当する診療 科は「一般内科」「循環器内科」「代謝・内分泌内科」 「消化器内科」「呼吸器内科」「血液 - 化学療法科」 「消化器外科」「精神科」「救命救急センター」の 9 部門である．各診療科の教授（臨床部長）は薬学部 の客員教授を兼務して，大学院生の「臨床研修」教 育に薬学部教員とともに責任を持つ. 大学院生の臨 床研修の一般目標及び行動目標を Table 1 に示し た。この臨床研修へは毎年 1 カ月の期間で，米国 University of Southern California (USC), Samford 大学，フランスの Nancy 大学の学生も参加する.

米国ジョージア州アトランタ市の Mercer 大学薬 学部の最終学年における APPE は 7 力所を 1 年 (30 週間) でローテートするが（'08-09 年度実習ガ イダンス)，その実習場所は一般内科，心臓内科，

Table 1. The GIO and the SBOs of Clinical Pharmacy Practice Training for Master's Students in Meijo University

GIO (一般目標)

臨床現場に模範となる薬剤師を提供するために, 臨床研修 を通して知識・技能及び生命倫理を理解し育む。

SBOs（行動目標）

1）診療現場（病棟/外来など）において, 診療のプロセス を理解する.

2）診療における臨床薬剤師の役割を理解し, 遂行できる.

3）医師，看護師など他の医療職種の役割を理解し協力で きる.

4）患者との良好なコミュニケーションをとり，かつ記録 することができる。

5）患者の愁訴, 病態・病状, 治療内容, 予後を理解でき る.

6）薬物療法の効果, 副作用（毒性/相互作用）をモニター できる
救急部，老年科，がん・血液内科，感染症部門，新 生児科，小巟科，ペインクリニック，精神科，外科 などであり，名城大学の技能コースの研修場所とよ く似た構成である。

技能コースでは，大学院生は医療チームの一員と して研修医，指導医とともに患者と接して，薬凨師 に何ができるか，彼らが患者のために果たさなけれ ばならない責任を彼ら自身によって考えさせる，米 国では「チーム医療」を interdisciplinary team care と呼ぶ，チームのメンバーはそれぞれの専門職能の 役割と責任を尊重し，理解して，協力することを意 味する．大学院生は 1 診療科を 3 力月毎にローテー トして，指導医，研修医，医学生らとともに行動 し，薬剤師としての責任は何かを学ぶ．臨床研修で の大学院生の典型的な 1 日の行動を Table 2 に示し た. 彼らは医局での勉強会, 症例検討会へ参加し, メールアドレスと病院情報システムへアクセスする パスワードを与えられ，医学部図書館の閲覧も許可 され，自由に利用することができる．臨床技能を学 ぶためにこれ以上の研修環境を用意することはでき ない。

4-2. サテライト・セミナー室における症例検討 会名城大学は藤田保健衛生大学医学部との連携 大学院教育の活動拠点として, 薬学部サテライト・ セミナー室 $\left(80 \mathrm{~m}^{2}\right)$ を連携先の医学部内に設けた. ここでは毎週，大学院生による症例検討会や医学部 教員による臨床医学セミナーが催される，症例検討 会は毎週水曜日の夕方に開かれ，指導医，薬学部教 員，薬剤師，時として米国の客員教員，米仏の留学 生も含めて議論される (Photo 1).

症例報告は発表する疾病に関する基本的情報の報 告から始める，主病名に関する疫学，その疾病の成 因 - 分類，病態生理，基本的な症状 - 身体所見，鑑 別診断・がんの場合の腫瘍マーカーなどの確定診断 根拠, 遺伝子診断, 学会や厚生労働省における研究 会の定める治療・薬物療法ガイドライン, 薬剤の主 たる副作用とそのパラメータ，予後因子など，基礎 的な客観情報を調査し，患者の疾病を背景として， 薬物療法モニタリングが報告される。ここでは PBL における仮説とその解決策，学習課題に相当 する部分が報告される．患者の疾病治療をエビデン スとして医学的水準を学習することで客観的に観察 し，理解する。医師の診療における局面には 4 つの 
Table 2. A Master's Student's Daily Schedule for Clinical Pharmacy Practice Training in a Clinical Site

\begin{tabular}{|c|c|}
\hline & 大学院生の臨床研修日程の 1 例 \\
\hline $8: 30-9: 00$ & $\begin{array}{l}\text { モーニングカンファランス：朝の研修医による患者症例報告会に参加し, 新たに入院した患者の診断・治療 } \\
\text { プロセスを理解する. }\end{array}$ \\
\hline $10: 00$ & 看護師申送り参加：看護師の勤務交替申送りに参加して, 夜間の患者の状態・症状の変化を確認する. \\
\hline $10: 00-12: 00$ & $\begin{array}{l}\text { 回診同行：主治医の回診に同行して, 診断のプロセスと患者を理解する. 副作用など医薬品情報を医師へ提 } \\
\text { 供する. }\end{array}$ \\
\hline $12: 00$ & 休憩（昼食・記録の整理） \\
\hline $13: 00-14: 00$ & $\begin{array}{l}\text { 患者諸検査等の理解 : 薬物療法の結果を監視するための諸デー夕を理解するため, 患者の受ける種々の検査 } \\
\text { に同伴し, 種々の検査の意義, 薬物療法との関連性を学ぶ. }\end{array}$ \\
\hline $14: 00-15: 00$ & 患者面接 : 担当患者と面接して, 薬物治療上の問題点（薬の効果・副作用など）を観察し, モニターする. \\
\hline $15: 00-17: 00$ & 服薬指導 : 患者に服用しているくすりを説明し, 患者自身が薬物療法に参加することの重要性を説明する. \\
\hline $17: 00-18: 00$ & 診療録記載：観察した患者情報・医薬品情報を医療スタッフに提供し，医師が診療録へ記載する. \\
\hline $18: 00-19: 00$ & $\begin{array}{l}\text { 医局症例検討会参加 : クルズス（症例を中心とした勉強会）へ参加して, 医師の患者診断, 治療計画・目標 } \\
\text { 設定を理解し, 必要に応じて医師へ患者情報・医薬品情報を提供する. }\end{array}$ \\
\hline
\end{tabular}

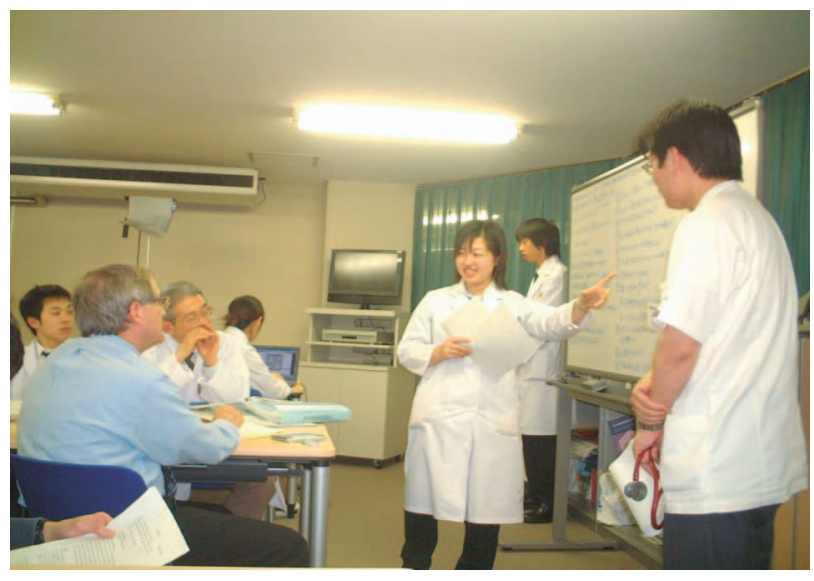

Photo 1. The clinical case conference held together with the visiting professor from Samford University, U.S. and the physician at the satellite seminar class room.

側面があるとされているが (後述), その場合の学 問的，医学的局面と患者の周囲の状況の考察にあた る部分である。ついで，下記に示すような患者基本 情報が報告される；CC， HPI， PMH， FH， SH， MEDs, ALL, ROS, Gen, Skin, HEENT, Lung/Thorax, CV, Abd, Genit/Rect, MS/Ext, Neuro, LABs な

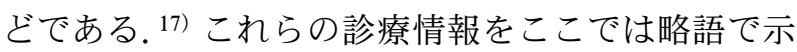
したが，大学院生はこれらの患者の基本情報を反映 して薬物療法を考察しなければならない。大学院生 が参加する Samford 大学の APPE での症例検討も 上記の略語が使われるため, あえてここでは略語で 表現した。これらは世界の医療従事者に共通の情報
である.

第 3 に患者の疾病の推移・薬物療法の推移, 薬剤 師としての介入が報告される。薬物療法の有効性と 有害作用を監視する最適なパラメー夕は何か，モニ タリングのための最適なパラメータを設定して, 薬 物療法の適切性をパラメトリックに判断する.これ らパラメータを Samford 大学では SKP (standard knowledge parameter）と呼ぶ. ${ }^{18)}$ あらゆる臨床情報 がパラメータになり得る。 その変動によって薬物療 法の推移を観察する。このような経験の蓄積が速や かで適切な薬物療法に係わる判断力を獲得すること となり, 熟達した臨床薬剤師としての専門職の㩚智 となる，新しい薬学教育では薬学生にバイタルサイ ンを教える. バイタルサインは患者の薬物療法の推 移を観察する重要なパラメータの 1 つである. 日本 の薬学教育にも変化の兆しがみえてきたといえよう.

4-3. 臨床研修の評価大学院生による報告は Table 3 に示した評価項目に従って形成的に評価さ れる。症例報告では種々な質疑が報告者と交わされ る. 適切な回答ができない場合は宿題となり, 再度 調査, 資料を整えて報告することとなる。「主治医 がそう言っていました」というような主体性のない 回答は許されない。もちろん発表者は調査の上自分 の意見として述べることが求められる. 大学院生の 研修を評価する最も重要な場が症例検討会である. 薬学教員にとってセミナーへの参加は臨床に接する 機会となり, 薬学教員の視点を臨床現場へ向けさせ 
る機会となつた効果は大きい。臨床研修における大 学院生の評価では，修士論文と臨床現場での彼らの 研修態度・姿勢が各診療科の指導医によって評価さ れる．大学院生は最終的に経験した症例から 1 例を 選択して修士論文にまとめる。

Table 3. Criteria for Assessing Master's Students Presenting Clinical Cases

(1) 発表態度 :

アイコンタクト/発表の速さ/資料をみないで発表する 能力/発表内容は適切である.

(2) 発表内容:

・患者の病態を説明している.

・患者のナラティブを理解している.

・標準的な薬物療法を理解している.

・薬物療法の効果と副作用をモニターし, 評価している.

・薬物療法の目標, 治療計画, モニタリング計画を立 案している.

(3) 配布資料:

SOAP を含めた適正な症例報告の書式を採用している. 適正な専門用語を使用し，適正な参考資料（論文等） を使用して EBM を理解している。

(4) 質疑の態度 :

質問の内容を理解し，適正に対応する.
1 期生から 6 期生までの 44 報の修士論文の内容 を分類すると，がん患者に関する論文が 18 例（40 \%）とがん関連の報告が最も多い。大学院生の臨床 現場での行動の評価は Table 1 に示した臨床研修の SBOs の各項目について，各診療科の指導医によつ て行われる（Fig. 4).

指導医による大学院生の評価は概ね「よくできた」 「できている」であったが，大学院生の自己評価は 「できなかつた」という反省の意図を含んだ評価が 入った，特に，指導医の評価が高いにも係わらず 「診療のプロセス」と「患者の愁訴, 病態・病状, 治療内容, 予後の理解」については $25 \%$ 強の大学 院生ができなかったとしていた．また，「薬物療法 の効果・副作用モニタリング」と「患者とのコミュ ニケーション」でも $22.2 \%$ の大学院生ができなか つたとしている。これら「診療プロセス」や「患者 を把握する」ことが困難であることは，従来の薬学 教育が現実の医療から遠い距離にあったことを示唆 しており，このアンケート結果は薬学教育に現場教 育の必要性・重要性を訴えていると解䣋されよう。

4-4. 医療における臨床倫理学的局面の理解 大学院生はこれらの臨床現場で患者や家族と触

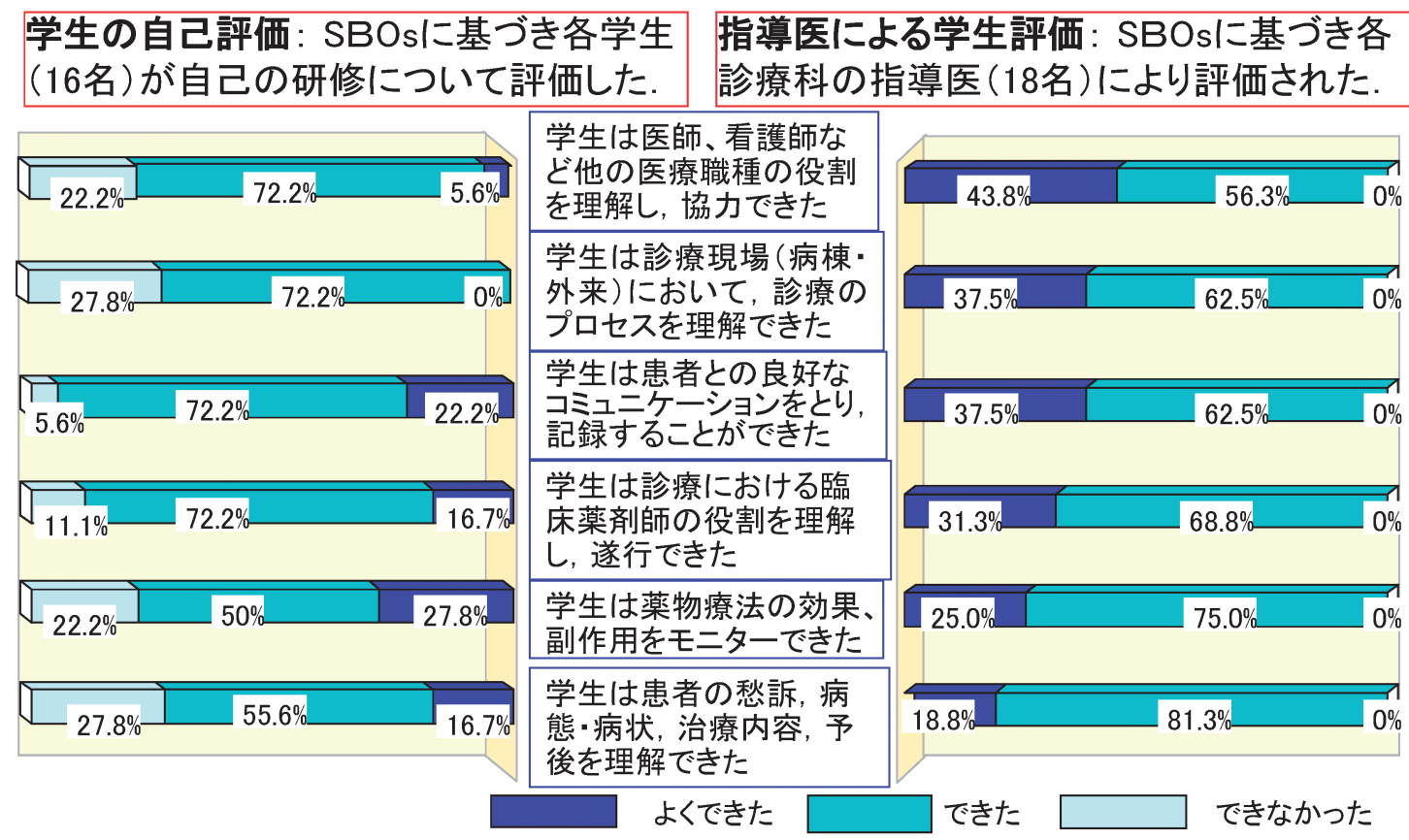

院生は8診療科 (一般内科, 循環器内科, 代謝·内分泌科, 消化器内科, 呼吸器内 科, 血液-化学療法科, 消化器外科, 精神科) と救命救急センターのうちの4診療科を 3カ月間単位でローテートして臨床研修に参加する。

Fig. 4. Assessment to Clinical Pharmacy Practice Training of Master's Students by Advising Physicians based on SBOs 
れ，患者の生活の背景と疾病の関係を知り，迫りく る死に直面する。このような体験は自然に大学院生 の倫理感を養い, 治療のエンドポイントや, 不確実 性の強い医療における倫理的な意思決定の過程を知 る。臨床倫理は時代背景による変化も交えて, 多岐 に渡る価值観を持つが，医療チームの一員として患 者に係わり，患者のこころを感じ，倫理的な対応を 大学院生たちは自然に備えるようになる。 Jonsen et al. ${ }^{19)}$ は診療における医療倫理的な患者対応を以 下の 4 つの側面から対応するとしている；1）進歩 した医療・医学のもたらす利益の適用，2）患者の 自律を背景とした患者の好み・意向，3）患者の QOL，4）患者の周囲の状況 ; 家族，社会，経済， 法律などの関係．大学院生たちは医療が EBM のみ では解決しないこと, 当面の治療目標, 患者の納得 する医療 narrative-based medicine に医療の意思決 定の要素があることを知る。これらは臨床現場だか らこそ学べる課題であり，疾病と患者を理解する道 である。

4-5. プリセプター養成の必要性 技能コース の弱点は薬学部教員が医療行ために加わらないた め，ベッドサイド教育に制約があり，実務指導者 mentor としての機能を十分に果たすことができな いことにある，将来のアドバンストな実務実習のた めにも，最も重要な課題は教育と現場指導のできる 薬学教育者を養成することである，米国の薬学教育 では臨床指導教員（プリセプター； preceptor）制 度が充実している，日本では医療施設に実務指導は 依頼されるが，今後の実習教育の発展は薬学教育者 自らがプリセプターとして活躍する環境を整えるこ とにある。

名城大学では, 技能コースを担当する病院薬学研 究室の准教授を精神科研究員に登録し，医師ととも に精神科外来診療に参加して, 精神科患者の薬物療 法，特に服薬指導による服薬アドヒアランス向上に 係わっている. ${ }^{20)}$ 薬学教員の医療の一線への参加は 臨床における薬剤師の存在を明確にし，学生がその 活動に接する教育効果は大きい.

4-6. 屋根瓦重層方式の臨床研修臨床技能 コースでは大学院生のローテーションの交代時や, 後輩の学生が初めて医療現場で研修を開始する場合 は 1-2 カ月間，後輩は先輩とともに行動し，医局の 習慣から情報の取り方など，臨床研修の具体的方法
を学ぶ，いわゆる屋根瓦重層方式が採用されている。

学習のピラミッド21)によれば講義の効果を $5 \%$ と すれば，実習による学習効果は $75 \%$ ，教える・使 つてみることによる学習の定着率は $80 \%$ とされて いる．先輩が後輩を指導することは「教えることに よって多くの新たな気づきと自らの臨床研修への反 省」となる機会を与える. 後輩指導によって得た先 輩学生の臨床研修への振り返りを紹介する。

屋根瓦方式の研修指導体制は研修医の指導では一 般的な方法である. 先輩が後輩を指導する方法は専 門職の世界では日常的で普遍的なことである．研修 者の身近な相談者として先輩が日常的な指導に携わ る. 技能コースにおける後輩指導も先輩にとつて臨 床研修の成果を省察する貴重な場であった．先輩大 学院生は,「自らの知識や活動内容の不足点を再認 識した」「自己の臨床薬剤師業務の問題点を再認識 できた」「下級生は患者情報，薬物療法，モニタリ ング，その整理・記録の方法など実践的に効率よく 習得した」と感想を述べている，上級生は下級生を 指導する方法とその時間の短さを反省しつつ，下級 生を指導することで自らの知識不足等を再認識でき た省察を得る。教えることによって得られる学習効 果である。

\section{5. 専門職の教育}

5-1. ファーマシューティカル・ケア 名城大 学の臨床薬剤師教育は, 米国の Pharm. D. 教育に “追い付け，追い越せ”の教育であった。かつて 1930 年代のアメリカの薬剤師はありふれた表現を すれば, “The pharmacist is the handmaiden of the physician.”と呼ばれ，医師との関係は消極的な関 係にあった. ${ }^{22)}$ 当時の米国の薬剤師は「忠実な調剂」 以外に薬剂師の責務はないと考えていた。しかし， 彼らはこの現状に飽き足らず，医療への役割を真剣 に考え，薬剤師の役割と責任を臨床的な方向へ傾斜 する努力を重ねた。この努力は教育と医療現場の双 方で行われた。その結果，米国の薬剤師教育は徐々 に臨床が理解できる実習を重視した教育へと変わつ ていった.

2005 年に米国臨床薬学会 $\mathrm{ACCP}^{23)}$ は実務家との 合同委員会 Joint Commission of Pharmacy Practitioners (JCPP) によって “Vision Statement: Pharmacists will be the health care professionals responsible for providing patient care that ensures optimal 
medication therapy outcomes.”と薬剤師のビジョン を打ち出している，さらに「薬学教育は薬剤師が薬 物治療を最適化して患者ケア，医療，予防を提供す ることを教育する」として，教育目標も調剤中心の 薬剤業務ではなくファーマシューティカル・ケアに あることを明確にしている。「薬剤師は意思のメイ ド」と自嘲した 1930 年代から，米国の薬剤師はこ こまで変ったのである．日本と米国の薬剤師教育の 違いはファーマシューティカル・ケアという教育目 標とそのスキル養成時間量にある．先ごろ訪問した Mercer 大学薬学部の実習時間（'08-09 年度）をみ ると，1-3 年は市中の薬局などで行われる初期実務 実習 (IPPE; introductory pharmacy practice experience）が実習講義を含めて各年度 100 時間，4 年生では年間 30 週で，その実習も診療サイトが中 心である。この教育姿勢が米国の薬剂師の存在感を 高めている. 米国の Pharm. D. 教育は現場薬剤師 と教育者のたゆみなき努力の歴史の結果である.

今，世界の薬剤師がファーマシューティカル・ケア を目標としている.

Samford 大の Henderson 教授は特色 GP シンポ ジウム（徳島大・名城大共催，徳島大で開催）の講 演6)で，APPE は専門職としての塜智 wisdom を体 得する場であると述べている。また松尾睦24)はスキ ル熟達のレベルを 5 段階；(1)初心者，(2)上級ビギ ナー, (3)一人前, (4)上級者, (5)熟達者, に分けて, 熟達者となるためには一般的に 10 年以上の期間を 要するとしている，認知能力は個別要素の把握，顕 著な特徵の把握，全体状況の把握と順次獲得し，最 終的に達する熟達者のその特長は「直感的に意思決 定」ができることにある。この意思決定はステレオ タイプな行動を指すのではなく，経験に裏打ちされ た直感的な問題解決のための意思決定こそが熟達者 の䟾智，すなわち技能の獲得である.

5-2. スペシャリスト？ プロフェッショナル ? 技能コースは薬学教育の領域に実務教育分野の確 立とファーマシューティカル・ケアを目指した教育 であった。 日本の薬剤師法が規定する薬剤師の主要 な役割は「調剤」であるが，米国の各州における pharmacy practice act がそうであるように，将来， 新たにファーマシューティカル・ケアが明記される ことを期待したい。技能コースの教育は専門性 specialty を持つ専門家 specialist 養成の前に，薬剤
師の役割と責任の理解し，社会に責任を持つ倫理観 を培った専門職 professional 養成を目指した。で は，専門職とは何か？ かつて，専門職と言えば, 聖職者，医師，弁護士であった。今日ではその意味 はより広範な職業を包含すると理解されている，専 門職とは 1）極めて多くのトレーニングと研究と学 問の発展を促す能力を有する，2）専門的な技能を 有した，3）専門職集団であり，4）倫理規定を持ち, 5）免許制度を有している職業である。今日では,

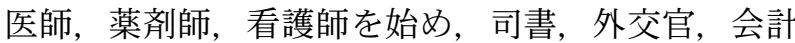
士，技術者，建築家，パイロット，ソーシャルワー カー，財政管理者，軍人，聖職者，研究者などのよ うな職業が専門職として例示される。今日では「公 共的使命 publicity と社会的責任 responsibility が強 く求められる職能」とされている（Fig. 5).25)

専門職の証となる「免許」の概念について，梅棹 忠夫 ${ }^{26)}$ は「(社会への) 情報操作の独占権の表現で あり，独占を認めることで情報（知識）の経済的価 值を生ぜしめる．社会的・公共性の強いものは国家 から特権を得ることによって, 経済活動となり得る ものである．技術上の免許は技術そのものが情報の 束（知識）であり，その知識を実地に適用すること は人命に係わるがために，免許は安全に対する国民 的合意（社会的責任）の上に成立している」と述べ ている．佐藤 25 は専門家の実践は実証科学を基盤と して，その実践，すなわち社会への技術・情報の還 元（適応）をするということが「科学的技術の合理 的適用」であるとした。専門職の実践の背景には親 学問としてのより精密な科学がバックアップする.

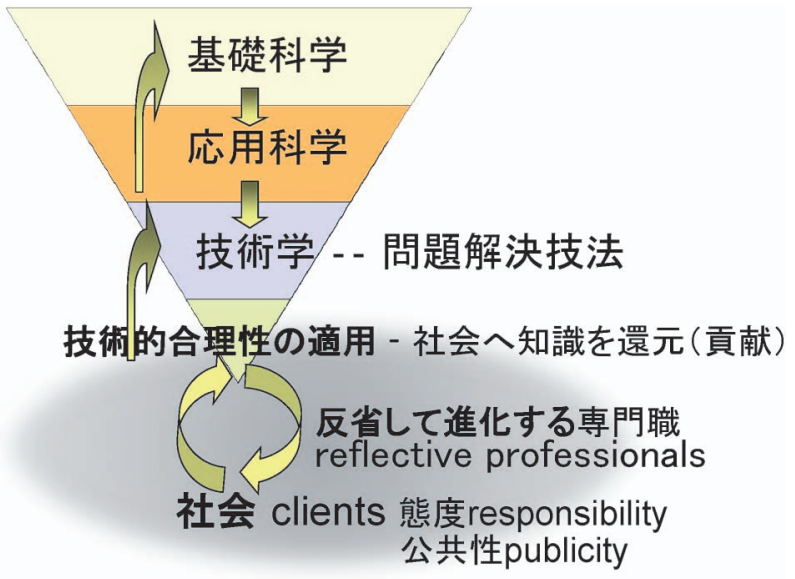

Fig. 5. Structure of Professionals 
専門職とは精密科学を社会へ具体的に技術的に適用 すべき技能を有する職能であり，その技術を 1 つの 学問分野として持ち，日々，省察を重ねることで独 自の技術学を確立している職業が専門職と解され る。 日本の薬剤師が真の専門職として成長するため には，薬剤師が専門職としての踥智を獲得するため の技能習得分野を確立しなければならない。名城大 学の臨床薬剂師教育は専門薬剂師 pharmacy specialist の養成ではなく，専門職としての薬剤師 Pharmacy Professional を目指した教育であった。

名城大学の臨床薬剂師教育の成功の一因は大学院 生がすでに薬剂師免許を取得しており，臨床現場で 薬剤師として行動することができたことであったこ とを述べておかなければならない，本教育は，平成 16 年度文部科学省特色 GP「医学教育と連携した臨 床薬剂師の養成」助成による成果である，名城大学 の臨床薬剂師教育への挑戦が今後の日本の薬学教育 発展の一石となることを願う。

謝辞医・薬連携大学院に全面的にご支援頂い た藤田保健衛生大学の歴代学長の馬嶋慶直先生, 船 曳孝彦先生, 中野浩先生, 現学長野村隆英先生及び 元医学部長で後に薬学教育へ参加してご協力を頂い た平野正美先生，現医学部長小野雄一郎先生及び各 診療科の教授及び諸先生方, 並びに名城大学の網中 政機, 兼松顯元学長, 歴代薬学部長の鈴木良雄教 授，金田典雄教授，現薬学部長岡田邦輔教授，それ に本学と国際交流協定結ぶ米国の Samford University, McWhoter School of Pharmacy の Drs. Joseph O. Dean, Charle D. Sands, Robert P. Henderson, Paula Thompson, Roger D. Lander をはじめとする all faculty of Samford University のご協力に深く感 謝致します，最後に技能コースを支えて頂きました 藤田保健衛生大学及び名城大学薬学部の全教職員の 方々に心より感謝し，お礼申しあげます。

\section{REFFERENCES}

1) Greenhalgh T., Hurwitz B., "Narrative Based Medicine," BMJ Book (1998) translated by Sato S., Yamamoto W., Kishimoto N., KONGOU-SHUPPAN, 2001.

2) Yamamoto W., Kishimoto N., "Practice of Narrative Based Medicine,” Kongo-Shuppan,
2003.

3) Hanya M., Matsuba K., Matsui T., Jpn. J. Pharm. Health Care Sci., 31, 606-619 (2005) .

4) Annual Report of Meijo University for Distinctive University Education Support Program (GP16) by MEXT, Meijo University, Faculty of Pharmacy, (2005).

5) Annual Report of Meijo University for Distinctive University Education Support Program (GP16) by MEXT, Meijo University, Faculty of Pharmacy, (2006) .

6) Annual Report of Meijo University for Distinctive University Education Support Program (GP16) by MEXT, Meijo University, Faculty of Pharmacy, (2007).

7) Annual Report of Meijo University for Distinctive University Education Support Program (GP16) by MEXT, Meijo University, Faculty of Pharmacy, (2008).

8) Kuebler-Ross E., "On Death and Dying," translated by Suzuki M., CHUKOBUNKO, 2001.

9) Watanabe Y., "Syougai-Gakusyuu Jidai no Seijinkyouiku-gaku,” Akashi-Shoten, 2000.

10) Knowles M. S., "Handbook of Adult Education in the United States," eds by Smith R. M, Aker G. F., Kidd J. R., The MacMillan Company, 1970.

11) Bloom B. S., "Handbook 1: Cognitive Domain," Longmans, N.Y., 1956.

12) Kawakita J., "Hassouhou," Chukoshinsha, 1967.

13) Kawakita J., "Zoku-Hassouhou," ChukoShinsha, 1970.

14) Kamei H., Hanya M., Hirano M., Matsuba K., Jpn. J. Pharm. Health Care Sci. 33, 235244 (2007).

15) Woods D. R., "Problem-based Learning How to Gain the Most from PBL," translated by Shinmichi Y., Igakushoin, 2001.

16) Candy B. R., Yarborough P. G., Annal. Pharmacother., 28, 1292-1296 (1994).

17) Schwinghammer T. L., Koehler J. M., "Pharmacotherapy Casebook: A Patient Focused Approach, 7th ed.," McGraw-Hill Companies, New York, 2008.

18) Monk-Tutor M. R., "Implementing ProblemBased Learning in Pharmacy," Samford University translated by Okamoto Y., Hirano 
M., Yoshida T., Kamei H., Hanya M., Nishida M., Matsuba K., Kaneda N., Meijo University, 2005.

19) Jonsen A. R., Siegler M., Winslade W. J., "Clinical Ethics: A Practical Approach to Ethical Decisions in Clinical Medicine 3rd ed.," translated by Akabayashi A., Ohi G., Shinko-Igaku-Syuppansha, 1997.

20) Takagi K., Kamei H., Nishida M., Matsuba K., Yamanouchi Y., Naito H., Iwata N., Jpn. J. Clin. Psychopharmacol., 11, 1491-1498 (2008)

21) Yoshida I., Ohnishi H., “Jissen PBL Tutorial
Guidance," NANZANDO, 2004.

22) Buerki R. A., Vottero L. D., "Ethical Responsibility in Pharmacy Practice," American Institute of the History of Pharmacy, Madison, 1996.

23）〈www.accp.com/report/rpt0405/art06.php $\rangle$.

24) Matsuo M., "Learning from Experience," DOUBUNKAN-SHUPPAN, 2006.

25) Sato M., Akiyama K., "The Reflective Practitioner," YURUMI-SHUPPAN, 2001.

26) Umezao T., "Joho-kogengaku," CYUOKOURON-SYA, 1988. 